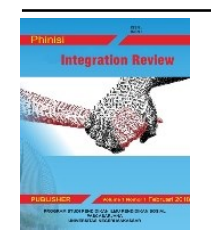

Phinisi Integration Review

Vol. 4, No.1, Februari 2021 Hal 1-13

Website: http://ojs.unm.ac.id/pir

p-ISSN: 2614-2325 dan e-ISSN: 2614-2317

DOI: https://doi.org/10.26858/pir.v4i1.19215

\title{
Usaha Perikanan Darat di Kabupaten Pangkajene 1989-1998
}

\author{
Khumairah Mansyur ${ }^{1}$, Ahmadin $^{2}$, Rasyid Ridha ${ }^{3}$ \\ ${ }^{123}$ Pendidikan Ilmu Pengetahuan, Universitas Negeri Makassar, Indonesia \\ ${ }^{1}$ Email: khumairahmansyur2001@gmail.com
}

\begin{abstract}
Abstrak. Penelitian ini difokuskan pada dampak dari adanya usaha perikanan darat di Kabupaten Pangkajene dan Kepulauan pada tahun 1989-1998. Penelitian ini merupakan jenis penelitian sejarah yang bersifat kualitatif dan merupakan jenis studi kasus yang didasarkan pada pendekatan teori mikro, komersial dan kelompok sosial untuk melakukan identifikasi serta interpretasi terhadap Usaha Perikanan Darat di Kabupaten Pangkajene dan Kepulauan. Secara metodologis, sumber data pada penelitian ini menggunakan jenis sumber kajian sejarah pada umumnya, yakni data primer yang diperoleh dari hasil observasi dan wawancara langsung dengan informan yang kemudian didukung oleh data sekunder berupa referensi tertulis seperti arsip, jurnal, buku dan berbagai media dan dokumentasi. Analisis data bersifat deskriptif, yakni menggambarkan dengan cara sistematik dan faktual terkait fenomena penelitian sehingga dapat menarik sebuah kesimpulan. Adanya Usaha Perikanan mengalami beberapa fase hingga dapat bertahan sampai sekarang ini. beberapa dampak dairi adanya Usaha Perikanan Darat yakni, lahirnya beberapa pengusaha lokal, peningkatan eknomi masyarakat dan pendapatan daerah. Pada bidang ekonomi, walaupun tidak semua kesejahteraan yang dirasakan oleh para pelaku usaha merata. Beberapa pelaku usaha seperti petambak, pengumpul dan penyalur cukup dan bahkan telah sampai pada titik perekonomian yang sukses. Tentu dari poin keberhasilan tersebut juga memberikan dampak bagi daerah, baik dari segi pendapatan daerah dan tentu nama baik dari daerah yang telah dijuluki sebagai Kota Bolu.
\end{abstract}

\section{Kata Kunci: Usaha, Perikanan, Perikanan Darat}

\begin{abstract}
This research is focused on the impact of the existence of inland fisheries business in Pangkajene and Kepulauan Regency in 1989-1998. This research is a type of historical research that is qualitative in nature and is a type of case study based on a micro, commercial and social group theory approach to identify and interpret Land Fishing Enterprises in Pangkajene and Kepulauan Regency. Methodologically, the data source in this study uses the type of historical study sources in general, namely primary data obtained from observations and direct interviews with informants who are then supported by secondary data in the form of written references such as archives, journals, books and various media and documentation. Data analysis is descriptive, that is to describe in a systematic and factual way related to the phenomenon of research so that it can draw a conclusion. The existence of the Fisheries Business underwent several phases to be able to survive until now. some of the impacts of the existence of the Inland Fishery Business namely, the birth of a number of local entrepreneurs, an increase in the community economy and regional income. In the economic field, although not all of the welfare felt by business people is evenly distributed. Some business actors such as farmers, collectors and distributors are sufficient and have even reached the point of a successful economy. Of course the success points also have an impact on the region, both in terms of regional income and of course the good name of the area that has been dubbed the City of Bolu.
\end{abstract}

Keywords: Business; Fisheries; Land Fisheries. 


\section{PENDAHULUAN}

Selain di Eropa, tradisi makan ikan telah menjadi bagian dalam kehidupan masyarakat nusantara. Selain ikan mengandung protein yang tinggi, pada tahun 1904 ikan juga merupakan sebuah menu utama bagi masyarakat Jawa. Pada satu sisi dengan adanya permintaan dan kebutuhan yang cukup besar, sehingga produksi ikan di masa itu menunjukkan kenaikan yang drastis, dalam hal ini baik berupa ikan segar maupun ikan kering. Pada sisi lain, ikan tidak hanya dijadikan sebagai permintaan untuk dikonsumsi, tapi disamping itu juga menjadi sumber pendapatan untuk para bangsawan yang mempunyai kekuasaan pada masing-masing daerah kekuasaannya karena ada terjadi sebuah ikatan kerja antara para pengusaha dengan bangsawan (Masyhuri, 1996:1-2)

Bagi orang Indonesia, Ikan Bandeng sudah dikenal oleh para nelayan sebagai makanan pelengkap di kolam istana. Itupun hanya dalam beberapa ekor saja dan tidak diketahui namanya. Pada masa perkembangan Kerajaan Majapahit sekitar 1350an, seorang raja menginginkan daging, para nelayan dititahkan untuk menangkap ikan tersebut secara besar-besaran untuk konsumsi raja Kerajaan Majapahit dan para kerabatnya. Waktu itu Ikan Bandeng tidak sembarangan dikonsumsi, hanya para raja dan kerabatnya atas izin raja, karena pada saat itu Ikan Bandeng dilindungi dari pihak kerajaan (Idel and Wibowo, 1996:12).

Seiring dengan kemajuan zaman dan runtuhnya Kerajaan Majapahit, maka rakyat pun diperbolehkan mengkonsumsi ikan sebagai lauk. Lalu terjadi kenaikan harga yang terus menanjak akibat banyaknya permintaan akan ikan tersebut. Akhirnya para nelayan membudidayakan ikan dalam keramba. Pembudidayaan ikan pada keramba ini kemudian diletakkan di tepi pantai. Setelah ikan tersebut sebesar tiga jari orang dewasa, barulah diangkat dan dipanen. Pada akhirnya karena ikan yang dibudidayakan semakin banyak dan berukuran agak besar sehingga dari pembudidayaan keramba ikan dipindahkan dalam sebuah kolam yang berukuran agak besar untuk mampu membuat/membudidayakan ikan dalam jumlah yang relatif banyak. Pada perjalanannya terjadi sebuah perang revolusi, tidak ada lagi petani atau nelayan yang memperhatikan dan memelihara ikan dalam kolam. Seiring dengan itu juga terjadi masalah seperti terjadi banjir besar yang kemudian menghanyutkan ikan pada kolam. Akan tetapi, sejarah pertambakan tidak semata lenyap karena kejadian tersebut.

Pada sekitar tahun 1950-an masyarakat Lamongan merintis dunia pertambakan air tawar (payau). Sebelumnya tanah masih berupa rawarawa yang tidak dimanfaatkan sama sekali. Dari sinilah akhirnya masyarakat luas ingin membudidayakan Ikan Bandeng di air tawar (Idel and Wibowo, 1996:12-13). Dalam hal ini Masyhuri mengkategorisasikan usaha perikanan menjadi dua, yaitu perikanan laut dan perikanan darat. Perikanan laut meliputi usaha perikanan yang orientasinya pada laut. Sedangkan usaha perikanan darat dilakukan di sungai-sungai, rawarawa, danau, pertambakan dan persawahan. Dari apa yang dijelaskan oleh Wibowo dan Masyhuri usaha perikanan terutama di darat memiliki peran penting dalam sejarah masyarakat sejarah di Indonesia.

Pada perkembangannya dari tahun ke tahun terus terjadi pembudidayaan ikan di air tawar dalam hal ini kolam tambak. Pembangunan perikanan masa Repelita $\mathrm{V}$ telah mengarah kepada suatu peningkatan kontribusi subsektor perikanan dalam hal ini menanggulangi dari berbagai permasalahan nasional, khsususnya pada bidang pertanian. Misalnya, menjamin adanya ketersediaan bahan pangan seperti protein hewani, peningkatan devisa, menciptakan lapangan kerja produkif dan peningkatan pendapatan nelayan/petambak ikan (Murtidjo, 1997:12). Semua itu tentu dilaksanakan dengan memperkuat posisi subsektor perikanan, khususnya nelayan dan petani ikan dengan tentunya tetap memperhatikan kepentingan dan kelestarian sumberdaya perikanan serta lingkungan hidup. Adapun sum berdaya yang tersedia terdiri dari jenis ikan yang memiliki keunggulan-keunggulan komparatif di pasaran internasional

Pengembangan budidaya ikan, khususnya bandeng tersebar dibeberapa provinsi di Indonesia seperti Nanggroe Aceh Darussalam (NAD), Lampung, Jawa Barat, Jawa Tengah, Jawa Timur, Nusa Tenggara Barat, Kalimantan Timur, Sulawesi Selatan dan Maluku Utara. Provinsi Sulawesi merupakan produsen bandeng kedua terbesar di Indonesia. Untuk pemasaran lokal, bandeng dijadikan sebagai komoditas unggulan dan produk olahannya menjadi makanan khas daerah. Pertumbuhan produksi bandeng di Sulawesi Selatan mengalami kenaikan sebesar 6,90 persen dari 59.999 ton tahun 2007 
menjadi 78.181 tahun 2010 (Kementerian Pertanian, 2013). Kabupaten Pangkajene dan Kepulauan merupakan salah satu kabupaten yang memiliki potensi tambak terbesar di pantai barat Sulawesi Selatan. Dengan berbagai perkembangan yang terjadi maka perlu kiranya membahas lebih lanjut persoalan usaha perikanan darat di Kabupaten Pangkajene dan Kepulauan.

Daerah yang sering dijuluki sebagai Tiga Dimensi adalah Kabupaten Pangkajene dan Kepulauan. Hal tersebut terlihat dari daratan, pegunungan, dan kepulauan yang membujur dari garis pantai barat ke timur yang terdiri dari persawahan, tambak, rawa-rawa dan perkebunan (Bagian Adm. Sumber Daya Alam Pemkab. Pangkep, 2013:1). Wilayah daerah kepulauan dan potensi kelautan dan perikanan adalah anugerah yang sudah di depan mata juga kekayaan alam atas bahan galian tambang mini memberi arti pada kelancaran denyut nadi ekonomi daerah. Kabupaten Pangkajene dan Kepulauan merupakan daerah yang memiliki identitas perikanan, terkhusus pada perikanan darat yang cukup menonjol. Hal tersebut dapat dibuktikan dari banyaknya tambak dibeberapa wilayah bahkan yang berada pada sisi jalan poros di sekitar jalan yang dilewati pada daerah tersebut serta kegiatan usaha budidaya di tambak serta penjualan Ikan Bandeng yang sudah menjadi mata pencaharian sebagian besar masyarakat di Kabupaten Pangkajene dan Kepulauan

Usaha perikanan darat meliputi budidaya tambak, budidaya kolam dan budidaya sawah, sampai kepada produksi dan penjualan. Usaha perikanan darat pada budidaya tambak adalah lahan yang berada pada dekat aliran sungai atau laut, karena air yang digunakan adalah air payau. Usaha perikanan darat pada budidaya tambak banyak digemari di Kabupaten Pangkajene dan Kepulauan karena tersedia banyak lahan. Usaha perikanan darat pada budidaya kolam adalah yang di desain untuk memungkinkan terjadinya aliran air dan pergantian air di dalam kolam. Namun pada tahun kajian peneliti, hasil produksi usaha perikanan darat pada budidaya kolam tidak melimpah, hal tersebut juga dikarenakan usaha pada budidaya kolam hanya pada satu daerah yaitu di Kecamatan Balocci. Kemudian usaha perikanan darat pada sawah, terdapat tiga pola pemeliharaan ikan di sawah, yakni pemeliharaan ikan sebagai penyelang, palawija dan pemeliharaan ikan bersama dengan padi (Effendi, 2012:33). Pola penyelang yang dimaksud ini adalah jenis pemeliharaan ikan di sawah sebagai penyelang di antara dua musim penanaman padi.
Ketika lahan pada sawah sedang tergenang karena habis panen menunggu pengolahan tanah berikutnya. Kegiatan ini tidak begitu ditekuni karena hasil tidak begitu banya, maka dari itu usaha ini dapat dikatakan tidak banyak diminati oleh masyarakat di Kecamatan Pangkajene dan Kepulauan. Pernyataan tersebut didukung oleh data yang didapatkan oleh peneliti terkait usaha perikanan pada lahan sawah. Pada tahun kajian peneliti tidak terdapat hasil produksi terkait usaha pada lahan sawah di Kabupaten Pangkajene dan Kepulauan.

Dari beberapa penjelasan di atas, terkait usaha perikanan darat yang akan dikaji oleh peneliti akan difokuskan pada usaha tambak yang membudidayakan hingga penjualan Ikan Bandeng. Sampai kepada penjualan yang prosesnya terjadilah ikatan kerjasama antara pembudidaya, pengumpul, penyalur sampai kepada pedagang-pedagang kecil seperti pedagang pasar. Peneliti terinspirasi dengan melihat kegiatan masyarakat pada bidang usaha perikanan darat, mulai dari budidaya, serta usaha jual-beli Ikan Bandeng, karena merupakan mata pencaharian masyarakat di Kabupaten Pangkajene dan Kepulauan. Selain itu, data yang didapatkan dari Badan Pusat Statsitik melalui subsektor perikanan menggambarkan data yang cukup melimpah persoalan hasil perikanan dan organisasi masyarakat yang menjadi bagian yang tidak dapat dipisahkan dari perkembangan usaha perikanan.

\section{TINJAUAN PUSTAKA}

Berusaha dan bekerja tentu tujuan utamanya adalah untuk memenuhi setiap kebutuhan hidup. Terkait kebutuhan keluarga bukan saja soal pangan, tetapi memenuhi pula kebutuhan sandang agar nyaman dalam beraktifitas serta kebutuhan papan untuk hidup mempunyai tempat berlindung yang layak. Salah satu jalan usaha yang patut ditempuh oleh keluarga berupa usaha perikanan darat, yang menjadi andalan masyarakat Pangkajene dan Kepulauan. Kesemuanya demi terwujud suatu keluarga yang sejahtera. Pada UU 31/2004 Bab 1 pasal 1 ayat 1 menyatakan bahwa perikanan adalah semua kegiatan yang berhubungan terkait pengelolaan dan pemanfaatan sumber daya ikan dan lingkungannya. Kegiatan yang dimaksudkan adalah mulai dari pra produksi, produksi, pengolahan sampai dengan pemasaran yang dilaksanakan dalam suatu sistem bisnis perikanan. Perikanan merupakan salah satu 
subsektor pertanian yang memegang peran penting dalam menyumbang angka pendapatan bagi negara maupun daerah karena sebagian besar wilayah negara Indonesia merupakan perairan sehingga sektor perikanan menjadi subsektor yang layak untuk dikembangkan di negara ini.

Perikanan terbagi atas dua aspek, yaitu perikanan laut dan perikanan darat. Perikanan laut merupakan suatu usaha yang orientasinya di laut. Usaha tersebut dilakukan di perairan pantai atau di tengah laut. Nelayan yang melakukan penangkapan di laut menggunakan dua cara yaitu penangkapan secara modern dan penangkapan secara tradisional. Sedangkan perikanan darat adalah kegiatan usaha yang dilakukan di daerah tambak, sungai, rawa dan bahkan di persawahan (Ahmad Yani, 2007:112). Indonesia sangat kaya dengan sungai, rawa, danau, telaga, sawah, tambak, dan laut. Kekayaan alam ini merupakan suatu anugerah ke arah pengembangan perikanan, baik perikanan darat maupun perikanan laut. Segala macam hasil perikanan merupakan sumber bahan makanan berprotein tinggi. Bahan itu sangat berguna untuk memenuhi kebutuhan gizi manusia agar tumbuh sehat. Negara yang warganya sehat akan menghasilkan potensi kerja yang tinggi dalam menunjang pembangunan bangsa (Sitanggang, 2006:11). Keberhasilan usaha perikanan darat dari budidaya ikan juga ditentukan oleh lingkungan terkait jenis tanah dan air. Jenis tanah sangatlah menentukan faktor keberhasilan dari budidaya air tawar, adapun jenis tanah yang baik untuk budidaya air tawar ialah jenis tanah liat atau lempung, karena tanah tersebut cocok digunakan untuk pembuatan tambak. Kemudian air sebagai media pada kehidupan ikan, jadi keberadaan air sangat mutlak diperlukan. Jumlah kualitas air harus selalu tersedia dan menjadi perhatian agar usaha budidaya ikan tersebut dapat seoptimal mungkin (Swadaya, 2008:25-26). Apabila dilihat dari tanahnya, Kabupaten Pangkajene dan Kepulauan merupakan wilayah yang potensial akan usaha perikanan. Daerahnya terletak di wilayah pesisir yang posisinya memanjang di Pantai Barat Sulawesi serta kandungan tanahnya yang menunjang. Hal inilah yang memungkinkan mengembangkan usaha perikanan cukup terbuka lebar.

Perikanan darat terdiri dari beberapa pelaku usaha, diantaranya pengelola/petambak dalam hal ini pembudidaya Ikan Bandeng, pengumpul, penyalur, pedagang dan pengusaha lokal seperti pemilik rumah makan. Para pedagang yang dimaksud adalah pedagang pasar ataupun pedagang yang berjualan di sepanjang pinggir jalan poros kota. Huub de Jonge dalam bukunya mengkategorikan usaha perikanan darat dalam orientasi pedagang kecil yang menjual ikan di pasar jalanan (De Jonge, 1989:128). Usaha perikanan darat yang dimaksud adalah para pedagang kecil yang hanya berjualan di pinggir pasar dengan jualan yang terbatas dan seadanya saja, biasanya ikan yang dibeli murah dari pengumpul atau bahkan dari pedagang yang mempunyai kios penjualan. Ada pula usaha perikanan darat yang bergerak dibagian usaha rumah makan. Petambak menjual hasil produksinya ke para pengumpul langganan, atau mereka menjualnya sendiri ke pasar sekaligus berdagang langsung berinteraksi dengan para pembeli. Pengumpul biasanya meneruskan penjualan ke pengusaha rumah makan, baik yang berada di daerah Pangkajene dan Kepulauan hingga ke restoran-restoran yang berada diluar daerah seperti di Kota Makassar. Tidak hanya itu, produksi ikan pada usaha perikanan darat ditiga daerah Kabupaten Pangkajene Kepulauan juga dijual ke perusahaan-perusahaan yang berada di Makassar dan daerah-daerah lainnya.

\section{METODE}

Metode yang digunakan pada penelitian ini adalah metode penelitian sejarah yang bersifat kualitatif. Gilbert J. Garragan, S.J memberikan defenisis mengenai metode sejarah adalah seperangkat asa dan aturan yang sistematik kemudian di desain guna membantu secara efektif dalam pengumpulan sumbersumber sejarah, menilainya secara kritis dan menyajikan sintesis hasil-hasil yang telah dicapai yang pada umumnya berbentuk tertulis (Daliman, 2012:27). Guna menjawab rumusan masalah penelitian yang telah ditetapkan, peneliti menggunakan metode sejarah dengan pendekatan penelitian kualitatif. Pendekatan kulitatif menekankan pada pembangunan sebuah naratif atau deskripsi tekstual terkait mengenai fenomena yang akan diteliti. Penelitian ini merupakan penelitian sejarah yang bersifat deskriptif analisis dengan tujuan untuk menemukan dan mendeskripsikan secara analitis serta menginterpretasikan terkait dengan Usaha Perikanan Darat di Kabupaten Pangkajene dan Kepulauan. Penelitian ini menggunakan desain penelitian kualitatif. Metode Penelitian kualitatif merupakan sebuah metode yang memfokuskan pada pemahaman fenomena sosial dari sudut 
pandang partisipan secara deskriptif. Dengan kata lain, metode ini lebih menekankan pada penelitian yang bersifat memberikan gambaran secara jelas dan sesuai dengan fakta di lapangan.

Penelitian menggunakan pendekatan kualitatif yang didasari atas beberapa alasan. Pertama, yang dikaji adalah makna dari suatu tindakan atau apa yang berada dibalik tindakan seseorang. Kedua, di dalam menghadapi lingkungan sosial, individu memiliki strategi bertindak yang tepat bagi dirinya sendiri, sehingga memerlukan pengkajian yang lebih mendalam. Penelitian kualitatif memberikan peluang bagi pengkajian mendalam terhadap suatu fenomena. Ketiga, penelitian tentang keyakinan, kesadaran dan tinglah individu dalam masyarakat sangat memungkinkan menggunakan penelitian kualitatif karena yang dikaji ialah fenomena yang tidak bersifat eksternal dan berada di dalam diri masing-masing individu.

Dalam mengawali suatu penelitian sejarah, maka langkah awal yang harus dilakukan adalah pengumpulan data. Dalam pengumpulan data, metode dalam studi sejarah adalah seperangkat aturan dan prinsip sistematis dalam mengumpulkan sumber-sumber sejarah secara sistematis, menilainya secara kritis. Berdasarkan uraian tersebut dapat disimpulkan bahwa metode sejarah merupakan cara atau teknik dalam merekonstruksi peristiwa masa lampau, melalui empat tahapan kerja yaitu Heuristik, Kritik sumber, Interpretasi, Historiografi.

\section{HASIL DAN PEMBAHASAN}

Pada bagian ini peneliti merangkum dampak yang diakibatkan dari usaha perikanan darat di Pangkajene dan Kepulauan. perihal teori yang digunakan untuk mengabstraksikan data yang telah dirangkum menjadi perhatian lebih peneliti, walaupun tidak secara utuh dijelaskan, tetapi teraktualisasi dalam kehidupan sehari-hari petambak. Perihal teori ekonomi mikro yang menjadi tumpuan mendasar dalam penelitian ini sepertinya cukup relevan digunakan untuk pengusaha ikan bandeng. Distribusi pasar menjadi bagian penting terciptanya pemerataan ekonomi seperti yang disampaikan oleh Adam Smith dalam teorinya tentang ekonomi mikro. Pendapatan berasal dari alam, sepertinya berubah menjadi usaha setiap individu. Para pengusaha dapat berinovasi secara berkelanjutan atas apa yang mereka lakukan, sehingga pemertaan pendapatan dapat dirasakan oleh masyarakat. Pada bagian ini dibahas mengenai lahirnya pengusaha lokal, peningkatan ekonomi masyarakat, dan pendapatan daerah.

\section{Lahirnya Pengusaha Lokal}

Usaha perikanan secara umum banyak dilakukan oleh masyarakat di Kabupaten Pangkajene dan Kepulauan. Mulai dari usaha budidaya hingga pemasaran Ikan Bandeng. Tiga kecamatan yang aktif dalam usaha perikanan adalah Kecamatan Pangkajene, Kecamatan Bungoro dan Kecamatan Labakkang. Berdasarkan kegiatan usaha dibidang perikanan tersebut khususnya pertambakan maka seiring waktu melahirkan beberapa pelaku yang berhasil dalam kegiatan tersebut. Maka dari itu beberapa pelaku usaha tersebut dianggap sebagai pengusaha lokal.

Pengusaha lokal lahir dari beberapa kegiatan usaha. Awalnya, usaha yang dilakukan masih berbasis kekeluargaan. Hingga seiring perkembangannya, terbentuk sebuah kelompokkelompok kecil yang saling bekerja sama dan kemudian masing-masing dari pengusaha kecil sukses dalam melakukan pemasaran. Mulai dari tingkatan daerah wilayah sekitar hingga mencakup jaringan ke daerah-daerah luar. Dari sisi sejarah, Kabupaten Pangkajene adalah derahyang memiliki potensi perikanan yang cukup besar. Beberapa masyarakat pesisir mahir dalam mengelola tambak. Dengan potensi wilayah yang mendukung serta kecakapan yang cukup, sedari kecil masyarakat sudah diperhadapkan dengan kegiatan pertambakan membuat mereka mahir dalam melakukan usaha tersebut.

Pada umumnya, hampir rata-rata masyarakat yang tinggal di daerah pinggiran pesisir dan daerah yang memiliki banyak lahan pertambakan menekuni pekerjaan tersebut. Beberapa pengusaha lokal lahir dari tingkatan bawah hingga mereka diakui sebagai

pengusaha lokal yang cukup sukses. Awalnya hanyalah seorang petambak, seorang pedagang Ikan Bandeng keliling. Kemudian menjadi pemilik tambak, pemodal hingga menjadi seorang pengumpul dan penyalur. Berdasarkan tiap tahunnya, jumlah rumah tangga perikanan dan rumah tangga buruh perikanan tambak tidak pernah mengalami penurunan. Hingga pada tahun 1993, tercatat sebanyak 1.797 Rumah Tangga Perikanan dan 1.004 Rumah Tangga Buruh Perikanan di Kabupaten Pangkajene dan kepulauan (Pangkajene dan Kepulauan dalam Angka 1993:206). Hal tersebut membuktikan kegemaran masyarakat dalam melakukan kegiatan dibidang perikanan darat. 
Keberhasilan usaha pemasaran Ikan Bandeng tergantung dari hasil dari budidaya produksi pertambakan. Semakin banyak Ikan Bandeng maka menjadi tantangan para pelaku usaha dalam melakukan kegiatan pemasaran. Produksi budidaya tambak pada tahun 1989 sebesar Rp. 20.551.000,00,- dan tahun 1990 sebesar Rp. 20.580.890.000.00,- (Pangkajene dan Kepulauan dalam Angka 1990:3). Dari setiap hasil produksi di siasati oleh para pelaku usaha dalam melakukan usaha pemasaran sehingga mendapatkan keuntungan yang cukup menjanjikan. Adapun rata-rata harga Ikan Bandeng yang menjadi acuan ataupun tolak ukur keuntungan di Kabupaten Pangkajene hingga pada tahun 1997 dijelaskan pada tabel 1.

Tabel 1. Rata-rata Harga Ikan Bandeng di Kabupaten Pangkep Tahun 1997

\begin{tabular}{llc}
\hline No & Bulan & $\begin{array}{c}\text { Harga Rata-Rata } \\
(\mathbf{R p} / \mathbf{K g})\end{array}$ \\
\hline 1 & Januari & 1.300 \\
\hline 2 & Februari & 1.300 \\
\hline 3 & Maret & 1.300 \\
\hline 4 & April & 1.300 \\
\hline 5 & Mei & 1.300 \\
\hline 6 & Juni & 1.300 \\
\hline 7 & Juli & 1.500 \\
\hline 8 & Agustus & 1.500 \\
\hline 9 & September & 1.500 \\
\hline 10 & Oktober & 2.000 \\
\hline 11 & November & 2.000 \\
\hline 12 & Desember & 2.000
\end{tabular}

(Sumber: Dinas Perikanan Kabupaten Pangkep)

Berdasarkan tabel 1 dijelaskan, rata-rata harga Ikan Bandeng yang menjadi acuan para pelaku usaha perikanan darat. Pada tahun 1997 terdapat dua kali kenaikan harga yakni terjadi pada awal bulan Juli dari harga Rp.1.300,00,menjadi Rp. 1.500,00,- dan pada bulan Oktober mengalami kenaikan hingga Rp. 2.000,00,(Pangkajene dan Kepulauan dalam Angka 1997:308). Kenaikan harga tersebut bersifat umum, dikarenakan dari tahun ke tahun kebutuhan pokok juga semakin naik. Kemudian, produksi Ikan Bandeng juga tidak pernah mengalami penurunan yang drastis bahkan mengalami kenaikan walaupun tidak signifikan. Kebutuhan dan permintaan para masyarakat juga tidak pernah ada habisnya, dikarenakan Ikan Bandeng merupakan kebutuhan pokok dalam kebutuhan sehari-hari. Masyarakat di Kabupaten
Pangkajene dan Kepulauan pada umumnya, Ikan Bandeng telah dijadikan sebagai menu makan dalam keseharian dari setiap rumah tangga. Dari banyaknya permintaan akan Ikan Bandeng dan seolah tidak pernah ada habisnya, baik permintaan dalam ruang lingkup daerah maupun luar daerah membuat para pelaku usaha selalu bersemangat dan yakin dalam melakukan kegiatan usaha pemasaran Ikan Bandeng. Para pelaku usaha, baik pengusaha kecil dan pengusaha lokal sukses selalu menanamkan bahwa usaha pemasaran Ikan Bandeng akan memberikan jalan keuntungan ditengah tantangan dan problema yang selalu dihadapi dalam menjalankan usaha tersebut.

Pada perkembangannya, kegiatan usaha masyarakat di Kabupaten Pangkajene dan Kepulauan telah tercermin dari para pendahulu dalam melakukan aktivitas perikanan, baik dalam budidaya dan perdagangan. Usaha yang dilakukan berupa semangat dan kemampuan para pelaku dalam menangani dan menjalankan usaha tersebut. Sehingga pada akhirnya akan membuka pula lapangan-lapangan pekerjaan kecil bagi masyarakat lain. Beberapa pelaku usaha yang dianggap sebagai pengusaha lokal di Kabupaten Pangkajene dan Kepulauan adalah H. Baha dan H. Burhan yang berasal dari Kecamatan Pangkajene dan Kecamatan Labakkang. pada dasarnya dalam membangun sebuah usaha terkadang masyarakat terkendala dalam segi modal. Namun, H. Burhan sebagai pengusaha lokal yang sukses dapat membuktikan dengan niat dan kerja keras adalah modal utama dalam menjalankan usaha. H. Burhan yang berangkat dari seorang pedagang ikan keliling kemudian mengumpulkan modal untuk membeli sedikit demi sedikit lahan tambak. Dari hasil lahan tambak milik sendiri kemudian menyewa lahan tambak hingga pada tahun 1990-an sukses dalam menjalankan usaha pemasaran Ikan Bandeng. Tentu tidak melalui perjalanan yang mudah hingga $H$. Burhan mendapatkan predikat pengusaha lokal. H. Baha yang pada awalnya memiliki modal awal dari mertua, kemudian fokus mempelajari usaha juga menghantarkannya menjadi pengusaha lokal. $\mathrm{H}$. Baha setiap harinya melakukan pengamatan kegiatan jual-beli di pasar. Mengamati harga jual serta membangun komunikasi dan relasi pada dengan petambak, pedagang dan pengusaha-pengusaha kecil. Sehingga pada akhirnya akan terjalin kerjasama yang berlanjut.

Para pengusaha lokal memiliki peran peting dalam kegiatan usaha, dalam hal ini yang 
dimaksudkan adalah perekonomian para pelaku saha yang berada dibawah mereka. Pengusaha lokal dianggap oleh beberapa pelaku usaha kecil sebagai pemodal. Maka dari itu kadang pengumpul dan penyalur sering diistilahkan sebagai punggawa, pemodal yang memegang predikat pengusaha lokal daerah. Peran pengusaha lokal terhadap para pedagang adalah saling melengkapi sebagaimana yang telah dijelaskan sebelumnya pada bagian usaha perikann darat pada bagian pemasaran. Pengusaha lokal dapat dikatakan sebagai salah satu titik nadi bagi para pedagang. Pada tahun 1990an, pengusaha lokal tidak banyak, dapat dihitung jari sekitar 4-5 orang. Pengambilan jualan Ikan Bandeng bagi para pedagang dapat dikatakan bergantung pada pengusaha lokal. Petambak menjual hasil panen Ikan Bandengnya ke para pengusaha lokal. Kemudian para pedagang pasar mengambil ikan dari para pengusaha lokal. Berbeda dengan sekarang ditahun 2000an sudah ada beberapa muncul pengusaha lokal (H. Baha. Wawancara. Pangkajene, 24 April 2020).

Namun kedua pengusaha lokal H. Baha dan $H$. Burhan tidak pernah lengser dari kedudukannya ditengah persaingan. Hal tersebut dikarenakan sistem kerjasama yang baik dipertahankan dan tentu tetap melakukan pemajuan-pemajuan dibidang pemasaran. Dilihat dari skemanya, hadirnya seorang pengusaha lokal dapat menggerakkan perekonomian kehidupan para pelaku usaha yang berkecimpung dibidang budidaya dan pedagang-pedagang kecil. Pengusaha lokal telah memiliki banyak pelanggan dan meringankan pemasaran bagi para petambak. Rata-rata yang ditemukan peneliti dalam melakukan wawancara kebeberapa petambak yakni di daerah Kecamatan Labakkang. Rata-rata para petambak menjual hasil panen Ikan Bandengnya ke H. Baha untuk memudahkan mereka dalam mendapatkan langsung bayaran dari hasil penjualan Ikan Bandeng tersebut. Beberapa petambak tersebut seperti, Daha, Rahim, Saibu, Kani' dan lainnya (Daha. Wawancara. Labakkang, 04 Februari 2020; Abd. Rahim. Wawancara. Labakkang, 04 Februari 2020; St. Saenab. Wawancara. Labakkang, 04 Februari 2020). Tentu yang membuat usaha perikanan darat khususnya Ikan Bandeng terkenal juga tidak lepas dari usaha para pengusaha lokal dalam melakukan pemasaran diberbagai luar daerah. Sehingga nama Kabupaten Pangkajene dan Kepulauan telah dikenal di berbagai daerah bahkan tingkat provinsi. Jaringan pemasaran yang telah dibangun para pengusaha lokal dalam melakukan kerjasama membawa pengusaha-pengusaha lokal lainnya yang berasal dari luar daerah, melirik Kabupaten Pangkajene dan Kepulauan sebagai salah satu pemasok Ikan Bandeng yang kerjasama pemasarannya masih terjalin hingga kini.

\section{Pembahasan}

\section{Peningkatan Ekonomi Masyarakat}

Indonesia merupakan negara kepulauan dengan jumlah pulau yang mencapai ribuan dan garis pantai yang luas. Terdiri dari kepulauan dan daratan. Keadaan tersebut menyebabkan kawasan pesisir menjadi sumber andalan pendapatan masyarakat. Indonesia memiliki kekayaan perikanan, baik laut maupun darat. Salah satu provinsi yang mengandalkan hasil perikanannya adalah Sulawesi Selatan. salah satu kabupaten di Sulawesi Selatan yang sangat produktif dibidang perikanan khusunya perikanan darat adalah di Kabupaten Pangkajene dan Kepulauan. Kawasan pertambakan yang kadang begitu kompleks dengan permasalahan memerlukan penanganan yang berkelanjutan. Walaupun pemerintah telah menugaskan penyuluh perikanan untuk mengontrol dan membantu keresahan para pelaku usaha dibidang perikanan darat. Namun, beberapa masyarakat atau pelaku usaha kadang masih terasa tersisihkan dan belum cukup. Kehidupan petambak yang bergantung pada sektor perikanan darat ada yang masih dalam tahap sederhana dan masih ada beberapa yang memerlukan uluran bantuan dari pemerintah.

Beberapa pelaku usaha dibidang perikanan darat ada yang mengalami keberhasilan dan masih ada pula yang hidup dalam berkecukupan. Khususnya masyarakat petambak yang beberapa diantaranya masih relatif tertinggal secara ekonomi. Dibandingkan dengan para pelaku usaha perikanan darat sebagai pengumpul dan penyalur. Padahal petambak adalah tombak keberhasilan bagi para pelaku usaha. Kondisi masyarakat petambak diberbagai kawasan daerah umumnya mengalami beberapa masalah, seperti ketidakcukupan dan kadang mengalami keterbelakangan sosial budaya. Kemudian rendahnya sumber daya manusia karena beberapa dari mereka hanya merupakan lulusan Sekolah Menengah Pertama (SMP) atau bahkan ada yang hanya lulusan Sekolah Menengah Atas (SMA). Beberapa masalah tersebut mencerminkan bahwa 
fungsi dari keberadaan usaha kelompok usaha masih lemah. Walaupun beberapa diantara pelaku usaha ada yang telah berhasil dan hidup sejahtera. Namun, dalam kenyataannya masih ada beberapa bahagian dari mereka yang tertinggal.

Kekayaan perikanan khususnya perikanan darat di Kabupaten Pangkajene dan Kepulauan mempunyai potensi yan tinggi. Terbukti dari hasil produksi setiap tahunnya. Beberapa kecamatan yakni Kecamatan Pangkajene, Kecamatan Bungoro dan Kecamatan Labakkang, selain telah mampu memenuhi permintaan masyarakat di Kabupaten Pangkajene dan Kepulauan. Beberapa kecamatan tersebut juga telah mampu memenuhi kebutuhan dari daerah lain, seperti Gowa, Jeneponto, Bantaeng, Sinjai, Bone dan lainnya. Hasil panen yang dimiliki telah mampu memiliki nilai jual. Akan lebih naik lagi ketika terkelola dengan baik. Peningkatan ekonomi tersebut bergantung terhadap aktivitas dari para pelaku usaha.

Pelaku usaha di Kabupaten Pangkajene dan Kepulauan ini memiliki beberapa kategorisasi, yakni petambak, pengumpul, penyalur dan pedagang pasar. Beberapa kesejahteraan hidup petambak masih ada yang hidup dalam berkecukupan. Hal tersebut dikarenakan kurangnya modal yang dimiliki dan beberapa tidak memili aset. Aset yang dimaksud adalah milik, seperti misalnya tidak memiliki lahan tambak. Sehingga mereka harus bekerja pada orang lain dan bergantung pada pemilik tambak. Adapun mereka yang masih hidup dalam taraf sederhana adalah pemilik yang tidak memiliki lahan yang begitu luas dan modal paspasan. Saibu dan Hasma yang merupakan sepasang suami istri, dari hasil penghasilan penjualan Ikan Bandengnya harus berbagi dengan anaknya. Kemudian sebahagian juga harus mereka sisihkan untuk pembayaran utang. Hingga kini, mereka menganggap bahwa kehidupannya kadang masih belum cukup. Anak pertama saya hanya tamat di bangku Sekolah Menengah Pertama (SMP). Mereka berharap untuk anak bungsunya bisa tamat sekolah sampai Sekolah Menengah Atas (SMA) dan melanjutkannya dibangku perkuliahan. Untuk mencukupi kebutuhan dalam menunggu panen hasil tambak maka Saibu dan Hasma juga mulai beternak bebek (Hasma. Wawancara. Labakkang, 04 Februari 2020).

Beberapa diantara petambak tentu akan mengalami beberapa masalah perekonomian. Namun, beberapa dari mereka juga mampu membuktikan kesejahteraan hidupnya dengan menjadi petambak. Ada juga beberapa petambak yang sudah hidup berkecukupan. H. Bahar dan $\mathrm{Hj}$. Halija sepasang suami istri mampu membuktikan dengan menjadi petambak sudah mampu mencukupi kebutuhan sehari-hari. Anakanak saya mampu mereka sekolahkan dan kebutuhan sehari-hari mampu mereka cukupi. Dengan berandalkan lahan tambak seluas 3 hektar, bahkan H. Bahar dan Hj. Halija sudah mampu menunaikan Haji dan memiliki rumah sendiri yang cukup besar dan nyaman untuk tempat bernaung bersama dengan anak-anaknya (H. Bahar. Wawancara. Bungoro, 04 Februari 2020). Setiap pelaku usaha khususnya petambak memiliki masalah yang berbeda-beda. Keberhasilan bergantung pada usaha mereka masing-masing. Tentu mereka membutuhkan modal yang cukup, modal fisik dalam melakukan aktivitas, modal finansial dan modal sosial.

Pendapatan ekonomi yang lebih tinggi, dirasakan oleh para pengumpul dan penyalur. $\mathrm{H}$. Burhan salah satu pengumpul yang bertempat tinggal di Kecamatan Labakkang telah mampu hidup berkecukupan dengan menjadi pengusaha ikan atau lebih sering disebut dengan pengumpul. $\mathrm{H}$. Burhan dan Hj. Hasma sepasang suami istri telah melakukan beberapa kali ibadah haji dan umrah. H. Burhan dan istri telah melakukan ibadah haji pertama pada tahun 1990 kemudian ditahun berikutnya 1995, 2000 dan 2004. Ibadah haji telah dilakukan sebanyak empat kali dengan selang lima tahun. Kemudian, H. Burhan telah melakukan ibadah umrah sebanyak tujuh kali. Sedangkan istri telah melaksanakan ibadah umrah sebanyak 14 kali. Beberapa keluarga yang lain seperti saudara dan kemanakan juga telah dinaikkan haji dan umrah. Terakhir pada tahun 2019 sedang didaftar 7 orang untuk ibadah haji dan menunggu untuk diberangkatkan. Untuk sanak keluarga yang beberapa masih bersekolah juga dibiayai oleh $\mathrm{H}$. Burhan dan istri $(H$. Burhan. Wawancara. Labakkang, 04 Februari 2020).

Walaupun terlihat jauh berkecukupan, $\mathrm{H}$. Burhan dan keluarga tetap hidup dengan cara sederhana. Beberapa lahan tambak telah dibeli untuk alasan perluasan. Sudah mampu mempekerjakan sekitar puluhan jumlah pegawai tambak dan juru pengantar ikan. Adanya usaha perikanan darat, ternyata mampu membawa beberapa kehidupan masyarakat menjadi lebih baik. Meningkatkan taraf ekonomi masyarakat melalui usaha-usaha yang telah diupayakan. Keberhasilan juga dirasakan oleh para penyalur. 
Salah satunya adalah $\mathrm{H}$. Baha yang dari tahun ke tahun bersyukur karena telah mampu mecukupi kebutuhan keluarga. Dari hasil pendapatan sebagai penyalur, $H$. Baha telah mampu menghantarkan istri menjadi seorang pengajar lulusan akhir master pendidikan. Selain itu, telah mampu menyekolahkan keempat anaknya. Adapun anak pertama merupakan mahasiswa lulusan jurusan kedokteran, kemudian yang kedua lulusan jurusan psikologi. Untuk anak ketiga dan keempat masing-masing duduk di bangku Sekolah Menengah Atas (SMA) dan Sekolah Dasar (SD). Saya menunaikan ibadah haji bersama istri dan ke empat anaknya. Setelah melakukan ibadah haji, kemudian melakukan ibadah umrah. Keempat anaknya telah melakukan ibadah haji sejak duduk dibangku Sekolah (H. Baha. Wawancara. Pangkajene, 24 April 2020).

Sebagai penyalur yang memiliki jiwa usaha, H. Baha lebih memilih untuk membeli lahan tambak dari hasil penghasilannya sebagai pengusaha ikan dibandingkan dengan membeli barang seperti kendaraan mobil. Menurutnya, dengan memperluas lahan tambak maka akan menambah tingkatan produksi. Sehingga akan lebih meningkatkan pendapatan. Kemudian lahan tambak ataupun lahan sawah merupakan investasi yang lebih memiliki harga jual kedepannya. Kehidupan dari beberapa pelaku usaha perikanan darat seperti petambak, pengumpul, penyalur, pedagang pasar hingga beberapa diantara mereka yang menuai keberhasilan masuk dalam kategori pengusahapengusaha lokal yang bergerak dibidang perikanan darat. Dapat dikatakan telah mampu menghidupi kebutuhan hidup sehari-hari. Beberapa diantara mereka ada yang masih berusaha, ada yang telah cukup berhasil dan bahkan telah berhasil. Kegiatan dibidang perikanan darat ini tentunya sangat membantu dan memberikan lapangan pekerjaan terhadap masyarakat-masyarakat yang sangat membutuhkan. Sehingga bidang perikanan juga dapat dikategorikan sebagai salah satu jenis pekerjaan yang mengurangi jumlah pengangguran di Kabupaten Pangkajene dan Kepulauan.

\section{Pendapatan Daerah}

Sulawesi Selatan merupakan salah satu provinsi yang memiliki potensi dibidang perikanan yang cukup besar. Hal tersebut ditunjukkan dengan besarnya kontribusi Sulawesi Selatan terhadap produksi perikanan
Indonesia. Sulawesi Selatan masuk kedalam lima peringkat terbesar terkait kontribusi perikanan terbesar terhadap Indonesia pada tahun (Muflikhati, Fannayanti and Yulianto, 1996). Pada kenyataan tersebut telah ditunjukkan bahwa Kabupaten Pangkajene dan Kepulauan yang merupakan salah satu pemasok perikanan di Sulawesi Selatan sesungguhnya mempunyai peranan besar dalam pembangunan perikanan. Tentu, perikanan tersebut masih dapat ditingkatkan dengan lebih memajukan pembangunan sektor perikanan dengan melihat potensi yang dimiliki Kabupaten Pangkajene dan Kepulauan cukup besar dan belum dimanfaatkan seoptimal mungkin.

Pendapatan daerah pada bidang perikanan darat terbanyak, terdapat dari Kecamatan Pangkaje'ne, Bungoro, dan Labakkang. Hasil penghasilan pemerintah yang berasal dari perikanan darat didapatkan dari distribusi pasar, izin perusahaan dan berbagai warung makanan yang didapatkan dari hasil tambak. Cakupan penghasilan pemerintah sangat bervariasi dari hasil perikanan darat. Jadi tidak hanya pada ikan bandengnya saja, tetapi segala yang berhubungan dengan usaha yang saling berkaitan dengan ikan tersebut menguntungkan pemerintah. Sebenarnya hubungan antara pengusaha, petambak dan pemerintah cukup harmonis. Dapat dilihat dari peranan pemerintah pada bagian sebelumnya, pemerintah memberikan bantuan kepada petambak. Sisi lain, petambak dan pengusaha mengeluarkan pajak sebagai pendapatan daerah. Adapun realisasi pendapatan daerah dapat digambarkan pada tabel 2.

Tabel 2. Realisasi Pendapatan Daerah Menurut Jenisnya (dalam ribuan rupiah)

\begin{tabular}{llc}
\hline No & $\begin{array}{l}\text { Jenis } \\
\text { Penerimaan }\end{array}$ & $\begin{array}{c}\text { Realisasi } \\
\text { Penerimaan }\end{array}$ \\
\hline 1 & Pasar & 176.250 \\
\hline 2 & $\begin{array}{l}\text { Tempat Parkir } \\
\text { Kendaraan }\end{array}$ & 3.500 \\
\hline
\end{tabular}

(Sumber: Diolah dari Badan Pusat Statistik, Pangkep dalam Angka 1993)

Berdasarkan tabel 1.2 di atas menujukkan realisasi pendapatan daerah lebih banyak didapatkan dari pasar. Dari yang telah digambarkan tempat parkir kendaraan merupakan pendapatan sebanyak Rp. 3.500,-serta realisasi penerimaan dari pasar Rp.76.250,- selama sehari. Dari gambaran ini dapat diasumsikan bahwa frekuensi dan barang yang dijual di pasar cukup banyak dan ramai. 
Menentukan target penerimaan pasar pemerintah harus pemgetahui berapa besar potensi retribusi pasar agar potensi tersebut dapat dioptimalkan untuk meningkatkan retribusi pasar. Potensi yang telah dipetakan oleh pemerintah menjadi target pemerintah. Target itulah akan dibandingkan dengan realisasi penerimaan retribusi pasar untuk mengukur tingkat penerimaan efektivitas penerimaan retribusi pasar. Efektivitas penerimaan retribusi pasar ditujukan untuk meningkatkan pendapatan asli daerah. Biasanya dalam penarikan retribusi pasar yaitu subjek dan obyek retribusi dan pelaksanan di lapangan. Adanya pengawasan yang ketat dari pemerintah dapat memaksimalkan pendapatan yang berasal dari pasar (Setiawan and Suprapti, 2002;134; Fauzan, 2016:219-220). Dari hasil wawancara dan data yang didapatkan sebelumnya bahwa pasar merupakan garda terdepan penjualan hasil perikanan darat. Pasar menjadi bagian yang penting dalam menentukan hasil pemasaran hasil tambak. Walaupun hasil yang didapatkan cukup banyak, tetapi tidak dapat dipasarkan secara baik, maka ikan yang didapatkan akan sia-sia. Dengan tingginya tingkat pendapatan pemerintah di pasar menujukkan bahwa mobilisasi penjual dan pembeli cukup bergairah. Dengan produksi perikanan yang telah dijelaskan cukup melimpah, maka hal ini mengantarkan hasil perikanan darat menjadi bagian penting dalam penerimaan pendapatan pemerintah yang didapatkan dari pasar.

Pada tabel 2 juga menujukkan bahwa angka pendapatan pasar memiliki perbedaan yang cukup mencolok dibandingkan dengan sektor lainnya. Apabila dibandingkan dengan hasil bumi yang notabene bergerak dibidang industri, lebih kecil pendapatannya. Apabila dibandingkan dengan daerah lainnya, industri merupakan bagian yang sangat penting bahkan andalan pendapatan daerah. Walaupun sebenarnya setiap daerah memiliki porsi pendapatan masing-masing, tetapi industri biasanya selalu mendapatkan perhatian yang lebih pemerintah. Pendapatan dalam sehari industri berupa hasil bumi sebanyak Rp. 81.000., sedangkan pasar pendapatan lebih dari duakali lipat sebanyak Rp. 176.250,-. Pada tahun 1993, dengan pendapatan perhari sebanyak itu, pemerintah dapat memperoleh penghasilan dalam 30 hari sebanyak Rp. 5.287.500,-. Jumlah yang cukup banyak pada era itu. Sebagai perumpamaan pada tahun yang sama, harga beras di Pasar Mappasaile sebanyak Rp. 470.- (dalam sekilo), apabila diakumulasi dengan jumlah pendapatan daerah dalam 30 hari, pemerintah mendapatkan $11.250 \mathrm{~kg}$ (11,25 ton) beras. Gambaran ini menujukkan bahwa pasar menjadi pendapatan yang cukup tinggi bagi daerah. Sebagai penghasil berasal dari perikanan darat yang tinggi dibandingkan wilayah lainnya di Sulawesi Selatan, maka dapat disumsikan bahwa pasar menjadi bagian utama mobilisasi ekonominya. Artinya, pemerintah mendapatkan pendapatan terbanyak sebenarnya berasal dari hasil perikanan darat. Pendapatan lainnya yang berasal dari perikanan darat dapat digambarkan pada tabel 3 .

Tabel 3. Target dan Realisasi Pendapatan Lain Daerah (dalam ribuan rupiah)

\begin{tabular}{llccc}
\hline No & $\begin{array}{l}\text { Jenis } \\
\text { Pendapatan }\end{array}$ & Target & Realisasi & Persen \\
\hline 1 & $\begin{array}{l}\text { Dinas } \\
\text { Perikanan } \\
\text { Daerah }\end{array}$ & 5.000 & 3.101 & 62,02 \\
\hline 2 & $\begin{array}{l}\text { Penjualan } \\
\text { Empang }\end{array}$ & 4.500 & 3.000 & 66,67 \\
\hline 3 & $\begin{array}{l}\text { Pemberian } \\
\text { Hak Atas } \\
\text { Tanah }\end{array}$ & 500 & 943 & 188,65 \\
\hline 4 & $\begin{array}{l}\text { Iuran } \\
\text { Pengairan }\end{array}$ & 1.500 & 17.864 & 1150,91 \\
\hline
\end{tabular}

(Sumber: Diolah dari Badan Pusat Statistik, Pangkep dalam Angka 1993)

Tabel 3 menujukkan bahwa realisasi pendapatan daerah paling banyak adalah iuran pengairan. Pada tahun 1993, terdapat perluasan wilayah perikanan darat yang cukup luas. Terdapat tanaman magrove yang ditebang, lalu dijadikan sebagai lahan usaha perikanan darat terutama tambak. Dalam usaha perluasan yang dilakukan oleh petambak, pemerintah membebankan petambak distribusi sebagai pendapatan daerah. Dengan jumlah distribusi yang cukup melimpah ini, seiring dengan adanya perluasan wilayah pertambakan. Dengan pertimbangan bahwa iuran pengairan memiliki realisasi pendapatan yang melebihi target. Pencapaian pendapatan daerah bahkan melebih target, lebih dari 1150,90 persen. Angka ini merupakan lonjakan yang cukup luar biasa. Parelel dengan hal tersebut, gambaran ini menujukkan bahwa perluasan yang melihi target seiring dengan bertambahnya jumlah perndapatan daerah.

Realisasi pendapatan daerah lainnya yang menjadi lumbung pendapatan adalah penjualan empang. Ternyata mobilisasi ekonomi, terutama 
penjualan tambak kepada sesama petambak dikenakan distribusi. Penjualan tambak ini menyentuh realisasi pendapatan wilayah sebanyak Rp. 3.000.-, perhari. Peneliti menempatkan pendapatan daerah berdasarkan realisasi yang dicapai, bukan berdasarkan pada targetnya. Pemerintah daerah juga memiliki sumber pendanaan sendiri berupa pendapatan asli daerah, pinjaman daerah, maupun lain-lain pendapatan yang sah. Pendapatan asli daerah (PAD) merupakan pendapatan daerah yang bersumber dari hasil pajak daerah, retribusi daerah, hasil pengelolaan kekayaan daerah yang dipisahkan dan lain- lain pendapatan daerah yang sah yang bertujuan memberikan keleluasaan kepada daerah dalam menggali pendanaan dalam pelaksanaan daerah. Fenomena umum yang dihadapi oleh sebagian besar Pemerintah Daerah di Indonesia dibidang keuangan daerah adalah bahwa dalam prakteknya pendanaan utama pemerintah daerah adalah bersumber dari dana perimbangan utamanya dana alokasi umum (DAU) dan bukan dari pendapatan asli daerah (PAD), karena hampir di setiap daerah proporsi pendapatan yang bersumber dari PAD begitu minim. Hal tersebut menunjukkan bahwa masih tingginya ketergantungan pemerintah daerah terhadap pasokan dana dari pemerintah pusat (Dewi, 2013:116). Maka realisasi yang tertinggi setelah iuran pengairan adalah penjualan empang sebanyak 66,67 persen. Tingginya realisasi pendapatan asli daerah, seiring dengan perkembangan mobilisasi pada sektor pertambakan di Pangkajene dan Kepulauan, terutama di Kecamatan Pangkaje'ne, Bungoro, dan Labakkang.

Pendapatan asli daerah yang penting bagi pangkep berasal dari Dinas Perikanan Daerah. Menariknya dari sumber yang diperoleh peneliti, Dinas Perikanan Daerah mendapat perhatian yang lebih dari pemerintah setempat. Salah satu sektor yang dicantumkan terbanyak pendapatannya adalah sektor tersebut. Hal ini menujukkan bahwa usaha perikanan memiliki geliat ekonomi yang cukup menggairahkan. Apabila dilihat dari luas wilayah tambak dengan realisasi pemberian atas hak tanah memiliki hubungan yang kuat. Luas area tambak apabila dirinci perkecamatan dapat digambarkan tabel 4 .
Tabel 4. Luas Areal Tambak Perkecamata di Kabupaten Pangkejene dan Kepulauan, 1990-1992

\begin{tabular}{llccc}
\hline No & Kec & $\mathbf{1 9 9 0}$ & $\mathbf{1 9 9 1}$ & $\mathbf{1 9 9 2}$ \\
\hline 1 & Pangkajene & $2.053,77$ & $2.331,99$ & $2.340,87$ \\
\hline 2 & Bungoro & 847,47 & 847,47 & 847,47 \\
\hline 3 & Labakkang & $2.514,03$ & $2.514,03$ & $2.514,03$ \\
\hline \multicolumn{4}{l}{ Sumber: Badan Pusat Statistik, } & Pangkep dalam \\
Angka 1993) & & &
\end{tabular}

Tabel 4 di atas menujukkan bahwa hanya Kecamatan Pangkajene yang mengalami perluasan wilayah disetiap tahunnya. Sedangkan kecamatan lainnya seperti Bungoro dan Labakkang, tidak mengalami perubahan sama sekali. Lokasi Pangkajene yang terletak di wilayah dekat pantai dan memiliki lokasi penanaman magrove yang cukup luas merupakan faktor yang dominan mempengaruhi, sedangkan di dua lokasi Bungoro dan Labakkang tidak mengalami penambahan sama sekali, karena lokasi ini lebih fokus pada produktivitas daripada perluasan wilayah. Distribusi pemberian atas hak tanah lebih banyak didapatkan dari Pangkajene, apabila dilihat pada tahun 1990 lahan seluas $2.053,77 \mathrm{Ha}$.

Pada saat tiga tahun setelahnnya pada tahun 1993 bertambah menjadi 2.340,87 Ha. Apabila diakumulasi pertambahan lahar tambak dalam tiga tahun sebanyak $287,1 \mathrm{Ha}$, apabila luas lapangan sepak bola resmi sebanyak 3,5 Ha, pertambahan luas area tambak sebanyak 82 kalilipat lapangan sepak bola. Dengan adanya perluasan wilayah di daerah Pangkajene inilah membuat pendapatan distribusi atas pemberian hak atas tanah bertambah sebanyak 188, 65 persen. Pada tahun 1993, ditargetkan Rp. 500.-, perhari, realisasi bertambah menjadi Rp. 943.-, perhari, hal tersebut disebabkan karena adanya perluasan wilayah Kecamatan Pangkajene.

Argumentasi di atas mengantarkan kita pada pandangan bahwa pendapatan asli daerah tidak bisa dilepaskan dari usaha perikanan darat. Berbagai pendapatan daerah yang berasal dari perikanan darat didapatkan dari penjual di pasar, perluasan lahan, pajak yang didapatkan dari dinas terkait. Jumlahnya cukup berpengaruh terhadap pendapatan daerah. Paralel dengan hal tersebut, segala yang dinikmati oleh pemerintah tidak bisa dilepaskan dari usaha dari petambak dengan memperdagangkan hasil yang didapatkan, terutama Ikan Bandeng. 


\section{SIMPULAN DAN SARAN}

Adanya Usaha Perikanan Darat memberkan beberapa dampak, yakni lahirnya beberapa pengusaha lokal, peningkatan eknomi masyarakat dan pendapatan daerah. Pada bidang ekonomi, walaupun tidak semua kesejahteraan yang dirasakan oleh para pelaku usaha merata. Beberapa pelaku usaha seperti petambak, pengumpul dan penyalur cukup dan bahkan telah sampai pada titik perekonomian yang sukses. Usaha perikanan darat juga memberikan lahan pekerjaan bagi para masyarakat pesisir khususnya dan para masyarakat yang tinggal di daerah tersedia banyak lahan pertambakan. Usaha perikanan darat terbukti dapat mensejahterahkan beberapa para pelaku usaha, seperti H. Burhan yang telah menunaikan Ibadah Haji sebanyak empat kali dan umrah sebanyak tujuh kali serta telah menyekolahkan beberapa keluarga. Penyalur bernama $\mathrm{H}$. Baha telah mampu memperluas lahan tambak dan mengembangkan jaringan usaha penjualan Ikan Bandeng. Bahkan banyak penyaluran Ikan Bandeng yang berasal dari Kabupaten Pangkajene dan Kepulauan yang di pasarkan di warung makan seperti di Boluta Makassar. Adanya usaha perikanan darat di Kabupaten Pangkajene dan Kepuluan dari keberhasilan usaha perikanan darat khususnya Ikan Bandeng membawa nama daerah Kabupaten Pangkajene dan Kepulauan menjadi daerah dengan ciri khas Kota Bolu.

Untuk kemajuan usaha dibidang perikanan darat, tentunya perlu modal yang cukup dalam menjalankan usaha tersebut. Saluran dana dari pemerintah terhadap para petambak untuk melakukan budidaya dan hasil panen sesuai dengan yang diharapkan juga perlu. Upaya bantuan pemerintah dalam melakukan pengajaran dan penyuluhan terhadap para petambak, kelompok petambak, pengumpul dan penyalur dapat terus dilaksanakan dengan memperhatikan akan kebutuhan masyarakat. Pengecekan dan turun langsung ke lapangan sesuai dengan sistem pelaksanaan yang sebagaimana harusnya.Untuk meningkatkan kontribusi pendapatan terhadap Pendapatan Asli Daerah maka diperlukan pengelolaan dan manajemen terhadap tenaga kerja yang terkoordinasi. Baik mengenai fasilitas, saran dan hal-hal pendukung lainnya. Terkait pengawasan Dinas Kelautan dan Perikanan perlu ditingkatkan mengenai data yang diolah. Penyusunan dokumen mengenai data statistik perikanan khususnya Ikan Bandeng dan data realisasi distribusi harus lebih diperhatikan.

\section{DAFTAR RUJUKAN}

Abd. Rahim. Wawancara. Labakkang, 04 Februari 2020. Kabupaten Pangkajene dan Kepulauan

Ahmad, T., Ratnawati, E. and Yakob, M. J. R. 1988. Budidaya bandeng secara intensif. Penebar swadaya.

Badan Pusat Statistik. 1990. Pangkajene dan Kepulauan dalam Angka 1990. Pangkep: Badan Pusat Statistik Kabupaten Pangkep.

Badan Pusat Statistik.1993. Pangkajene dan Kepulauan dalam Angka 1993. Pangkep: Badan Pusat Statistik Kabupaten Pangkep.

Badan Pusat Statistik. 1997. Pangkajene dan Kepulauan dalam Angka 1997. Pangkep: Badan Pusat Statistik Kabupaten Pangkep.

Bagian Adm. Sumber Daya Alam Pemkab. Pangkep. 2013. Bagian Adm. Sumber Daya Alam Pemkab. Pangkep, 2013. Potensi Sumber Daya Alam Kab. Pangkajene dan Kepulauan 2012. Bagian Adm. Sumber Daya Alam Pemkab. Pangkep.

Daha. Wawancara. Labakkang, 04 Februari 2020. Kabupaten Pangkajene dan Kepulauan

Daliman, A. 2012. Metode penelitian sejarah. Penerbit Ombak.

Dewi, G. Pengaruh Realisasi Pendapatan Asli Daerah, Dana Alokasi Umum dan Dana Alokasi Khusus Terhadap Target Pendapatan Daerah (Survei Pada Kabupaten/kota Se-Sulawesi Tengah), Katalogis, 1(1).

Effendi, I. 2012. Budidaya Perikanan.

Fauzan, A. 2016. Analisis Potensi Penerimaan Retribusi Pasar Sebagai Salah Satu Sumber Pendapatan Asli Daerah Kabupaten Hulu Sungai Utara. Jurnal Ekonomi Pembangunan, 13(2), pp. 218225.

H. Baha. Wawancara. Pangkajene, 24 April 2020. Kabupaten Pangkajene dan Kepulauan. 
H. Bahar. Wawancara. Bungoro, 04 Februari 2020. Kabupaten Pangkajene dan Kepulauan

H. Burhan. Wawancara. Labakkang, 04 Februari 2020. Kabupaten Pangkajene dan Kepulauan

Hasma. Wawancara. Labakkang, 04 Februari 2020 . Kabupaten Pangkajene dan Kepulauan

Idel, A. and Wibowo, S. 1996. Budidaya Tambak Bandeng Modern. Surabaya: Gitamedia Press.

De Jonge, H. 1989. Madura Dalam Empat Zaman: Pedagang, Perkembangan Ekonomi, dan Islam: Suatu Studi Antropologi Ekonomi. Diterbitkan atas kerja sama Perwakilan Koninklijk Instituut voor Taal-, Land.

Masyhuri, P. S. U. 1996. Menyisir Pantai Utara. Yogyakarta: Yayasan Pustaka Nusatama.

Muflikhati, I., Fannayanti, N. and Yulianto, G. 1996. Peranan Subsektor Perikanan dalam Perekonomian Wilayah Jawa Sarat.1(3), pp. 1-14.

Murtidjo, B. A. 1997. Budi daya kakap dalam tambak dan keramba. Kanisius.

Pertanian, K. 2013. Direktorat Jenderal Pengolahan dan Pemasaran Hasil Pertanian, Market Intelligence, Kakao Andalan Ekspor Indonesia, 11(1).

Setiawan, S. and Suprapti, E. 2020. Perpajakan. Malang. UMM Press.

Sitanggang, M. 2006. Budidaya Gurame, Budi Daya Gurami.

St. Saenab. Wawancara. Labakkang, 04 Februari 2020. Kabupaten Pangkajene dan Kepulauan.

Swadaya, T. P. P. 2008. Agribisnis Perikanan. Penebar Swadaya. Jakarta.

Yani, A. 2007. Geografi. Jakarta: Penerbit Grafindo. 